\title{
Sport ethics: A history, task, and future
}

\author{
Sungjoo Park* \\ Kookmin University
}

\begin{abstract}
[Purpose] This study aims to contemplate the identity and significance of sport ethics as an independent academic field by examining how it began and developed, where it is now, and where it will or should be moving forward. [Methods] First, a history of sports philosophy which gave birth to sport ethics is surveyed. Second, the emergence of sport ethics in the historical development of sport philosophy is analyzed. Third, major methodologies and theoretical frames of sport ethics are introduced. Last, what needs to be done in South Korea in relation to sport ethics is suggested. [Results] Sport ethics in the future is expected to resort to interdisciplinary approaches which combine a variety of academic disciplines and methodologies. In addition, sport ethics must relate its theory to practice. The pressing task for sport ethics in South Korea is to establish its identity as a separate academic field. In order to do this, we should figure out what to study in sport ethics, and continue to study about the range, methodology, and theoretical frame of sport ethics. [Conclusions] The establishment and development of an academic field becomes only possible when fully supported by numerous scholars' work, practical achievement of the field, and a diversity of policy and institution, and a continued discussion and agreement on the content and methods of the discipline. In order to enhance its status as well as professionalism of sport ethics scholars, researchers of various academic backgrounds should study sport ethics, exchange ideas on theory and methodology, and spread results of studies through education, guiding through the development of sports.
\end{abstract}

Key words: Sport ethics, Sport philosophy, History, Task, Prospect

\begin{abstract}
서 론
최근 쇼트트랙 국가대표인 한 여성 선수가 자신의 코 치에게 미성년자 시절부터 상습적인 폭행과 성폭행을 당 했다는 사실이 알려지면서 우리사회에 큰 충격을 안겨주 었다. 이 선수의 용기 있는 폭로 이후 유도, 정구, 태권도 등 각 종목에서 성폭력 피해 고발이 잇따르며 스포츠강국 의 화려함 속에 감춰졌던 부끄러운 민낮이 드러났고, 이 에 스포츠계가 발칵 뒤집혔다. 지난 수십 년간 '국위 선양' 이라는 미명 아래 극한의 경쟁 체제와 승리지상주의에 내
\end{abstract}

논문 투고일 : 2019. 03. 15.

논문 수정일 : 2019. 04. 08.

게재 확정일 : 2019. 04. 12.

* 교신저자 : 박성주(sjpark54@kookmin.ac.kr).
몰리며 인권의 사각지대에 방치된 엘리트체육 선수들의 피해가 위험 수위를 넘었다고 판단한 정부는 스포츠계 개 혁의 칼을 빼 들었다. 체육계 스스로는 자정능력의 발휘 가 어렵다고 판단했는지 문화체육관광부, 여성가족부, 교육부가 국가인권위원회 등과 협력을 통해 범정부 차원 에서 체육계에 깊게 자리 잡고 있는 고질적 병폐를 근본 적으로 없애겠다며 종합대책을 발표했다. 정부가 발표한 범정부 차원의 체육계 비리근절 대책 중 눈에 띄는 대목 은 '스포츠윤리센터'의 설립이다. 국민체육진흥법을 개정 하여 스포츠분야의 비리 조사와 조정, 중재 등을 총괄하 는 독립기구로 스포츠윤리센터를 설립·운영하여 공정한 스포츠 환경을 조성하겠다는 것이다.

'스포츠윤리'는 다분히 학술적인 용어임에도 불구하고 언제부턴가 '스포츠윤리'라는 단어가 급작스럽게 유행하 
고 있다. 체 육지도자들이 스포츠윤리를 기본 소양으로 배 우고 체득할 수 있도록 2015년부터 체육지도자 자격검정 시험에 스포츠윤리가 필수과목으로 신설되었다. 또한 대 학에서 스포츠윤리 교과목을 개설한 학과가 급증하고 있 으며, 체육단체 및 기관에서 운영하는 지도자 및 심판 교 육프로그램에도 스포츠윤리가 교육내용으로 추가되고 있다. 하지만 이처럼 스포츠윤리에 대한 사회적 관심과 유행에도 불구하고 '스포츠윤리가 무엇이냐'라는 질문에 답변을 할 수 있는 사람은 그렇게 많지는 않을 것이다. 다 시 말해, 스포츠윤리가 단순히 일상적인 용어로 사용되고 있을 뿐 스포츠윤리가 무엇을 다루는 것이고, 어떻게 교 육할 수 있는가에 대한 논의가 선행되어 있지 않다. 이로 인해, 대학과 스포츠현장에서 스포츠윤리교육을 실시한 다고는 하지만 무엇을 가르치고, 어떻게 가르치는지는 그 것을 교육하는 사람에 따라 달라질 수밖에 없고 스포츠윤 리 관련 전문 정보를 얻을 수 있는 소스(source)도 턱없 이 부족한 실정이다.

스포츠계에 페어플레이, 스포츠맨십, 공정성 등과 같 은 윤리에 대한 요구는 늘 있어왔다. 하지만 근래에 들어 요구의 정도가 심상치 않다. 많은 사람들이 스포츠에 윤 리를 찾는 이유는 역설적으로 스포츠에 윤리가 그만큼 결 핍되어 있다는 것의 반영일 것이다. 즉, 스포츠에서 윤리 가 절실하다는 것은 스포츠가 그만큼 윤리적으로 병들어 있다는 반증이라고 할 수 있다. 실제로 최근 국민적 공분 을 일으킨 성폭력 사건뿐만 아니라 승부조작, 도핑, 심판 매수, 불법도박, 음주운전, 폭행 등 도덕적 해이와 관련된 사건들이 스포츠계에서 끊이지 않고 발생하고 있다.

스포츠윤리에 관한 유행은 학계에서도 마찬가지이다. 스포츠윤리에 대한 사회적 관심 고조로 도핑, 스포츠맨 십, 성차별, 속임수, 승부조작, 페어플레이 등과 같은 주 제를 다루는 학술 논문들이 최근 들어 한국체육철학회지 를 중심으로 상당 수 게재되고 있다(Kim, Kim, \& Park, 2017). 하지만 주제 연구에 비해, 스포츠윤리가 무엇인 지, 스포츠윤리의 궁극적 목적과 대상은 무엇이고, 이 대 상을 어떤 방법으로 연구할 것인지, 스포츠윤리를 하나의 학문으로 성립시키는 방법론적 근거들은 있는지 등과 같 은 스포츠윤리학 자체에 관한 고찰은 지금껏 아주 소수의 연구에서만, 아주 부분적으로 이루어졌다. 즉, 스포츠윤 리 관련 논문편수는 양적으로 급증하고 있으나 하나의 학 문 분야로서 스포츠윤리가 어떠한 위치에 있으며 어떻게 나아가야 하는지에 대한 심도 있는 고찰의 노력들은 상대
적으로 부족한 실정이다.

국내에서 스포츠윤리에 대한 논의가 본격적으로 시작 된 지 그렇게 오래되지 않은 현실을 감안하면 지금까지 국내 스포츠윤리에 관심을 둔 학자들의 많은 연구 성과는 고무적인 일이다. 하지만 이러한 관심과 연구 성과의 양 적인 확산 속에 스포츠윤리학이 과연 무엇을 하는 학문이 며, 어떻게 해야 하는가와 같은 스포츠윤리의 학문적 정 체성에 관한 심도 있는 반성과 논의는 결여되었던 것이 사실이다. 그 결과 국내 스포츠윤리학은 다른 학문과 구 분되는 독립적인 정합성과 체계성을 갖추지 못하고, 학문 적 발전도 이루어지지 않고 있다.

이에 본고는 하나의 학문으로서 스포츠윤리학의 정체 성과 의의를 성찰하는 근본적인 목적을 가지고, 스포츠윤 리학이 어디에서부터 시작되고, 어떻게 성장해 왔으며, 현 재 어떠한 위치에 와 있고, 향후 어떻게 나아갈 것인지, 그 리고 나아가야 하는지에 대해 구체적으로 살펴보고자 한 다. 이를 위해, 먼저 스포츠윤리학의 모(母) 학문이라 할 수 있는 스포츠철학의 역사를 살펴보고, 둘째, 스포츠철학 의 역사적 과정에서 스포츠윤리학의 등장과 그 배경을 분 석하며, 셋째, 스포츠윤리 연구의 주요 방법론과 이론적 틀을 고찰하고, 끝으로 미래 스포츠윤리학의 과제와 전망 을 제시하고자 한다. 이러한 연구는 스포츠윤리학을 전체 적으로 조망할 수 있는 토대가 될 것이고 스포츠윤리 연 구 및 스포츠윤리교육의 방향성을 제시할 수 있을 것이다.

\section{스포츠철학의 역사}

어떠한 대상이 무엇인지를 본질적으로 파악하려면 그 것이 언제, 어디서, 어떻게 만들어졌는지를 알아야 한다 ( $\mathrm{Sim}, 2013)$. 따라서 스포츠윤리학의 정체성과 의의를 탐구하려면 먼저 이 학문이 어떻게 생성되고 발전되었는 지를 파악하는 것이 필요하다. 스포츠윤리학의 성립과 발 전을 알아보기 위해서는 그 부모 학문이라 할 수 있는 스 포츠철학의 역사를 먼저 살펴보지 않을 수 없다.

스포츠철학은 북미에서 처음 정립되어 유럽과 나머지 세계로 뺃어나갔다. 스포츠철학(the philosophy of sport) 은 애초 체육(교육)철학(the philosophy of physical education)이라 불렸고, 철학이라기보다 교육철학의 하위분 야로 여겨진 체육철학에 대한 비판적 반응으로부터 발전 되었다. 영국과 미국의 체육철학의 주요 목적은 모든 형 
태의 체육활동, 즉 기본적 움직임이나 자발적 놀이부터 고도로 조직화된 게임이나 스포츠를 아우르는 체육활동 의 교육적 가치를 공고히 하는 것이었다. 체 육철학자들은 종종 절박하게 이러한 과업을 수행해나갔는데, 왜냐하면 1960년대 이전의 선두적인 교육이론가들이 체육교육은 지적, 인지적 내용을 결여했기에 적절한 교과목이 아니라 고 여겼기 때문이다. 달리 말하면, 당시의 지배적 견해는 체육교육이 정신보다는 신체(몸)에 관련된 것이기에 전 통적인 교육의 일부가 될 수 없다는 것이었다(Morgan, 2006). 그러므로 당시의 체육철학자들이 이런 비뚤어진 견해를 낳은 조잡한 신체-정신 이원론을 약화시키기 위 해 최선을 다했음을 쉽게 짐작할 수 있다.

그러나 1960년대 중후반 미국에서 스포츠철학이 체육 철학을 퇴색시키고 학문적 주제와 학술적 관심의 중심이 되었다. 이러한 중요한 지적 전환은 부분적으로는 1960 년대 중반 미국과 세계 각지에서 일어나기 시작한 스포츠 에 대한 폭발적 관심 덕분으로 볼 수 있다. 이와 더불어 스포츠에 관한 철학적 관심의 증가는 미국에서 발생한 두 가지 주요한 변화 때문이다. 하나는 스포츠 연구를 철학 적 지도에 올려놓은 세 편의 선구적 저서의 등장이었고, 다른 하나는 미국에서 상대적으로 무명인 한 대학에서 만 들어진 체육교육의 교양교육(liberal arts) 모델 때문이 었다(McNamee \& Morgan, 2017). 이 모델은 스포츠철 학을 교과과정의 핵심에 놓았고, 스포츠의 철학적 중요성 에 관한 담론에 시동을 걸어 종국에는 더 큰 학계로 퍼져 나가게 하였다.

먼저 스포츠철학에 관한 두 획기적 텍스트는 남 캘리포 니아 대학(University of Southern California) 체육교 육과 교수들에 의해 집필되었다. Howard Slusher의『인 간, 스포츠, 존재(Man, Sport, and Existence)』(1967) 와 Eleanor Metheny의『움직임과 의미 (Movement and Meaning)』(1968)가 그것이다. Slusher의 책은 스포츠 참 여의 중요성과 의미에 관한 존재론적 접근이다. Metheny 의 선구적인 책은 보다 독창적이고, 인간의 움직임과 스 포츠에 관해 완성된 철학 이론을 담고 있다. 이 책들의 잇 따른 출판은 스포츠철학이란 새로운 연구 분야를 추동해 나갔으며, 고등교육과 학계에서 체육철학자들이 누려온 지배력에 종지부를 찍는데 중추적 역할을 했다( $\mathrm{McNamee}$ $\&$ Morgan, 2017). 이러한 선구적 텍스트들 덕분에 철학 계 내부에서 스포츠철학이 주목을 받기 시작하고는 있었 지만 긍정적인 주목만은 아닌 상황이었다. 이러한 상황에
서 스포츠철학의 학문적 위상에 가장 큰 공헌을 한 책은 Paul Weiss의 『스포츠: 철학적 질문(Sport: A Philosoph-

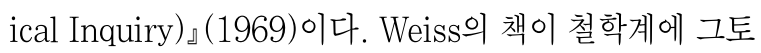
록 큰 반향을 일으킨 이유는 책 자체의 지적 우수성이라 기보다 철학계와 학계에서 Weiss가 차지하는 위치 때문 이었다(Fraleigh, 1983). Weiss는 미국의 최고 철학자 중 한 명이자 철학계 밖에서도 가장 칭송받는 대변인 중의 하나로 널리 존경받고 있었다. Weiss 같이 세계적 명성 의 철학자가 스포츠에 관해 책 한 권을 쓸 만한 가치가 있 다고 여겼다면, 이 주제를 보다 진지하게 봐야 되지 않겠 냐는 생각이 당시 인문학자들에게 들었던 것이다.

물론 Weiss가 스포츠에 관해 쓴 유일한 철학자는 아니 었다. 플라톤, 아리스토텔레스 같은 철학의 거장들도 놀 이와 경기, 스포츠에 관해 그 중요성을 옹호하거나 권장 하는 글을 썼고, 니체, 하이데거, 사르트르 같은 권위자들 의 세계관에서도 놀이가 꽤 중요한 위치를 차지했다. 20 세기의 유명한 오스트리아인 분석철학자 비트겐슈타인 (Wittgenstein) 역시 스포츠철학을 논할 때 빼놓을 수 없 는 학자인데, 언어 게임이란 개념을 이용해 그의 가장 독창 적인 철학적 견해의 일부를 설명했기 때문이다(Fraleigh, 1983). 비록 이들 철학자들 중 아무도 Weiss처럼 체계적인 스포츠철학 저서나 논문을 펴낸 사람은 없지만 그들이 스 포츠와 놀이에 관해 쓴 문구와 부분들은 결코 사소하지 않 다. 이러한 사실에도 불구하고 당대 철학자들은 스포츠를 단순히 무시하며, 진지한 철학적 관심이나 분석의 대상이 되기에 하찮은 것이라 단정지어 버렸다(Morgan, 2006).

스포츠철학이 학계의 인정을 받게 된 두 번째 배경은 학 계 내에서의 제도화와 관련 있다. 1960년 말, 70 년대 초에 이르면 미국과 캐나다 대학의 체육교육과에서 스포츠 연 구에 주목하기 시작하며 그 결과로 교과과정을 완전히 재 편하였다. 가장 주목할 만한 경우는 브락포트(Brockport) 에 있는 뉴욕 주립대(The State University of New York) 인데, 총장인 Albert Brown이 체육교육과의 변화를 주도 하였다(Ryall, 2016). Brown은 아주 새롭고도 중요한 변 형을 가해 학위를 주는 학부과정으로 체육교육 전공을 개 발하도록 제안하였다(Fraleigh, 1983). 그 변형은 보다 널 리 퍼진 전통적 교육이나 전문적인 모델보다 교양교육에 바탕을 둔 모델에 기반을 두라는 것이었다. Brown은 이 어 1970년 산 호세 주립대(San Jose State University)에 있던 Warren Fraleigh를 고용해 체육교육 및 레크리에 이션 대학 학장으로 임명하고 체육교육 교과과정을 바꾸 
는 프로그램을 수행토록 했다(Andrieu, 2014). Fraleigh 는 여섯 명의 스포츠철학 전공자 및 스포츠사회학 분야 학자들을 고용했고 스포츠철학을 새 교과과정의 핵심 과 목 중 하나로 만들었다. 이처럼 유사한 전공 분야에 관심 을 가지고 연구하는 학자들을 한 자리에 모아놓는 것은 그 규모에 있어서도 다시 되풀이되기 힘들만한 엄청난 혁 신이었고, 이는 미국과 캐나다 전역의 체육교육과에도 상 당한 영향을 미쳤다(McNamee \& Morgan, 2017).

브락포트는 '철학 상호교환 센터(The Center for Philosophic Exchange)'가 있는 곳이었다. 이 센터의 목적은 시급한 사회적 공공 이슈에 대한 철학적 분석을 장려하고 분석 결과들을 학계와 공적 영역에 널리 퍼뜨리는 것이 었다(Ryall, 2016). 이러한 임무를 위해 센터는 해마다 두 명의 저명한 철학자들을 초청하여 중요한 사회적 이 슈에 대해 심층적인 토론의 장을 마련하였다. 그리고 비 디오녹화를 해서 관심 있는 교육기관과 공공 조직에 무 료로 배포하였다. 초청받은 두 철학자는 청중 앞에서 논 문을 발표해야했고, 이어『철학 상호교환(Philosophical Exchange)』이란 학술지에 그 논문을 출판했다. 1971년, Fraleigh는 Paul Weiss를 센터로 초청하여 스포츠에 관 한 논문을 발표하게 하고, 그리고 당시 떠오르던 일리노 이대 (University of Illinois) 철학자 Richard Schacht 를 모셔 Weiss의 스포츠철학 논문을 비평하게 하는 스 포츠철학 심포지움을 기획하였다(McNamee \& Morgan, 2017). 그 다음 해인, 1972년 Fraleigh의 계획대로 Weiss 와 Schacht의 토론을 필두로 북미에서 처음으로 온전히 스포츠철학에 관한 학술대회가 열렸는데, 이것이 바로 최초의 공식적인 스포츠철학 학술대회로 인정되고 있다 (Ryall, 2016).

$\operatorname{Morgan}(2006)$ 의 언급에 따르면, 첫 스포츠철학 학술 대회는 대단한 성 공이었는데, 수많은 철학자들과 철학 훈 련을 받은 체육학자들이 여러 세션에서 논문을 발표하고 참석자들 사이에 열띤 토론도 진행되었다고 한다. 이러한 성공적 학술대회에 힘입어 Fraleigh와 Weiss는 스포츠 철학 학회를 설립하고 스포츠철학 학술지를 시작하는 것 에 관해 논의였다(Ryall, 2016). 이러한 목적으로 운영 위원회가 만들어졌는데, Fraleigh와 Weiss 외에도 철학자 Richard Zaner, 스포츠철학자 Ellen Gerber가 운영위원 회에 포함되었다(Fraleigh, 1983). 1972년 보스턴에서 열 린 미국 철학협회 동부지부 회의(Eastern Division Meeting of the American Philosophical Association)에서 '스
포츠 연구를 위한 철학 학회(The Philosophic Society for the Study of Sport, PSSS)'가 공식적으로 설립되었다. 그 다음 해, 『스포츠 철학 저널(Journal of the Philosophy of Sport)』이라 불리는 새 학술지를 창간하기 위한 계획 이 세워졌고, 브락포트의 스포츠철학 교수였다가 미네 소타 대학(University of Minnesota)으로 옮긴 Robert Osterhoudt가 첫 편집인으로 임명되었다(McNamee \& Morgan, 2017). 창간호는 1974년 출판되었다. 1999년, '스포츠 연구를 위한 철학 학회(PSSS)'는 늘어나는 국제 회원 수를 고려해 '국제 스포츠철학 협회(International Association of the Philosophy of Sport, IAPS)'로 공 식 명칭을 변경했다. 오늘날 이 국제 스포츠철학 협회는 탄탄하고 활기찬 학술 조직으로 전 세계에서 연례 학술대 회를 개최하고 있으며, 대표 출판물인 『스포츠 철학 저널 (Journal of the Philosophy of Sport)』역시 이 분야의 최고 저널 중 하나로 자리매김하였다.

물론 스포츠철학이 북미에서 가장 왕성하게 발전했지 만, 다른 국가에서도 스포츠철학 분야의 발전과 조직화가 이루어졌다. 1970년대 독일에서도 '독일 스포츠과학 협회 (German Society of Sports Science')에 스포츠철학 분과 가 포함되어 있었다. 독일 스포츠철학에서 중요한 초기 작 업은 Hans Lenk라는 유명한 철학자에 의해 수행되었다. 『운동경기의 사회철학(Social Philosophy of Athletics)』이 라는 그의 저서가 1975년 독일에서 출판되었고 1976년에 영어로 번역되어 나왔다(McNamee \& Morgan, 2017). 이 와 비슷하게 일본도 '일본 스포츠 연구 협회(Japan $\mathrm{So}^{-}$ ciety for the Study of Sport)' 내에 스포츠철학 학회가 만 들어졌고, 스포츠 및 체육교육 철학 저널(Journal of the Philosophy of Sport and Physical Education』을 출판 하기 시작했다(Hata \& Sekine, 2010)

영국에서의 스포츠철학 발전 양상은 초기에 체육교육 철학과 관계있었다는 점에서 미국과 비슷하다. 영국 스포 츠철학에서 고전이라 할 수 있는 한 권의 유명한 책이 출 간되는데, 영국 철학자 David Best의『철학과 인간의 움 직임(Philosophy and Human Movement)』(1978)이 그 것이다. 이 책은 무용을 포함시키고 있어 단지 스포츠에만 초점을 맞춘 책이라고 할 수는 없다. 이 책의 특징은 스포 츠철학의 초기 현상학적 연구를 매우 비평적으로 보며, 스포츠의 지위를 예술로 보는 것에 관한 논쟁을 출발시켰 고 이 논쟁은 수십 년간 지속되었다(Martinkova \& Parry, 2012). 스포츠철학에 관한 연구 활동이 활발히 진행되었 
음에도 불구하고 영국에서는 2002년이 되어서야 스포츠 철학에 관한 하나의 협회가 설립되었다. 이것은 '영국 스포 츠철학 협회 (British Philosophy of Sport Association, BPSA)'로, 글로스터셔 대학(University of Gloucestershire)의 Mike McNamee가 조직한 학술대회에서 시작되 었다. 이 협회는 또한 『스포츠, 윤리학, 철학(Sport, Ethics, and Philosophy)』이란 학술지를 출판하기 시작했는데, 이 학술지는 곧 스포츠에 관한 철학적 연구를 출판하는 주요 국제지가 되었다. 영국스포츠철학협회는 2003년부터 매 해 연례회의를 개최했고 세계 각지로부터 발표자들을 초 청하여 스포츠철학 연구 모임을 만들었는데, 여기서 '스포 츠철학을 위한 유럽 협회 (European Association for the Philosophy of Sport, EAPS)'가 결성되었다(McNamee \& Morgan, 2017).

미국, 특히 『스포츠 철학 저널 (Journal of the Philosophy of Sport』에 게재되는 스포츠철학 연구와 영국 및 유 럽에서의 연구에는 철학적으로 흥미로운 차이가 존재한 다. 이 차이점은 미국과 캐나다에서는 스포츠에 관해 분 석철학적 접근이 지배적이지만, 영국과 유럽에서는 대륙 철학 전통에서 연구하는 철학자들이 실존주의, 해석학, 존재론, 현상학 같은 분야의 전문가들만 이해할 수 있는 훨씬 특화된 언어로 스포츠를 분석한 문헌이 주를 이루었 다(Ryall, 2016). 물론 한국, 대만, 일본과 같은 아시아권 국가에서는 동양철학을 토대로 스포츠에 접근한 문헌들 도 많이 출판되고 있다.

한편 국내에서 스포츠에 대한 철학적 탐구가 본격적으 로 시작된 시기는 1990년대 이후로 볼 수 있다. 그 시작 은 1991년 4월 연세대학교 교수회관에서 스포츠와 무용 에 관한 철학적 연구에 관심을 가진 소수의 체육학자들이 학회 창립을 위한 발기인 모집 모임이었다(Lee, 2002). 그리고 다음 달인 5 월에 창립총회를 거쳐 이화여자대학교 김종선 교수를 초대회장으로 추대하여 한국스포츠·무용 철학회가 창립되었다. 그 해 8 월에 제 1 회 '국제 스포츠.무 용철학 세미나'를 열었으며, 다음 해인 1992년 5월에는 국내 체육철학자 10 인의 논문과 더불어 미국의 스포츠철 학자 Seymour Kleinman, 일본의 Yoshidaka Kondo와 Akido Kadaoka 교수의 논문을 묶어『움직임의 철학: 한 국스포츠·무용철학회지 (Philosophy of Movement: The Journal of Korean Society for the Philosophy of Sport and Dance)』제 1 권을 창간하였다(Lee, 2002). 이후 2000 년 6월 학회명칭을 '한국체육철학회'로 변경하였다. 창간
호부터 2016년까지 한국체육철학회지에 게재된 논문 수 는 1,137 편에 달하며, 특히 1990년대 이후 한국 스포츠 철학은 양적뿐만 아니라 질적으로 빠른 속도로 성장하고 있다(Kim, Kim, \& Park, 2017).

\section{스포츠윤리학의 등장과 배경}

\section{스포츠윤리학의 역사적 개관}

스포츠철학의 역사는 꽤 오래되었다고 할 수 있지만, 윤리학의 관점과 원리를 활용하여 스포츠현상과 대상을 체계적으로 이해하고 설명하려는 스포츠윤리학의 역사는 그에 비해 최근의 일이다. 스포츠윤리학은 윤리학을 토대 로 두고, 스포츠상황에서의 윤리적 판단 또는 윤리적 행동 의 기준과 조건을 제시하기 위해 도덕의 본질적인 문제를 탐구하는 스포츠철학의 한 분과라고 할 수 있다. 1970년 대 스포츠선수들의 경기력향상약물에 의한 도핑 관련 사 건들이 세계 스포츠계의 주요한 이슈로 떠올랐고, 1980년 대부터는 다양한 형태의 도핑뿐만 아니라 스포츠에서 동 물의 권리, 폭력, 동성애, 평등, 인권, 정책 및 환경윤리에 이르기까지 폭 넓은 주제에 관한 윤리적 담론이 형성되기 시작했다(Kang, 2013; Park, 2014; Song, 2015). 오늘 날 자본주의 경제체재 속에서 스포츠의 상업화가 급속도 로 진행됨에 따라 스포츠의 본질과 정체성을 퇴색시키는 사건, 사고가 지속적으로 발생하며 스포츠현장에서 윤리 적 판단이 필요한 상황들이 더욱 증가하게 되었다(Park, 2016). 미국 스포츠철학회는 1970년대 중반 이후 스포츠 에서 발생하는 다양한 현상에 대한 윤리학적 논의를 본격 적으로 다루기 시작했다.

굳이 스포츠윤리학의 시초라고 한다면 플라톤과 아리 스토텔레스로 돌아가 그들이 체육(체조와 운동경기)을 통 한 좋은(도덕적) 삶에 대해 언급한 문헌을 떠올릴 수 있다 (Reid, 2012). 우리가 오늘날 스포츠라 인식하는 매우 제 도화된 상태는 대개 빅토리아 시대 영국에서 시작되었다 고 여겨지며, 이 당시 스포츠 관련 텍스트에서 상당한 윤리 적 성찰이 발견된다(Holt, 1989; Mangan, 1981, 1987; McIntosh, 1979; McNamee, 2017; Renson, 2009). 스 포츠윤리에 더욱 구체적으로 관련 있는 자료는 피에르 드 쿠베르탱 남작의 성찰로서, 그의 방대한 글들에 올림피즘 의 개념, 스포츠와 종교적 규범성, 풍성한 윤리적 내용을 
가진 국제 올림픽 위원회의 공식적 이념과 철학이 담겨져 있다(DaCosta, 2006; McLaughlin \& Torres, 2011; McNamee, 2006; McNamee \& Parry, 1998; Parry, 2006).

학술적 개념을 갖추었다고 할 수 있는 스포츠윤리학 초 기상태의 자료는 1983 년 Scott Kretchmar의 글에서 발 견할 수 있는데, 그는 스포츠 속 속임수와 도덕성, 스포츠 맨십, 그리고 Fraleigh와 McIntosh의 스포츠윤리와 관련 된 몇몇 논문들을 다루었다. 최초의 스포츠윤리학에 관한 저서는 1984년 Warren Fraleigh의 『스포츠에서 올바른 행 동: 참가자를 위한 윤리(Right Actions in Sport: Ethics for Contestants)』로, 미국에서 스포츠철학회가 한창 활 발히 운영되던 시기에 출판되었다. 이 책은 Fraleigh의 두 가지 주요 관심 분야였던 철학과 체육교육을 합친 것이라 할 수 있다(Ryall, 2016). Fraleigh는 스포츠 참가자들에 게 일관되고도 철학적으로 튼튼한 '의무 시스템'을 만들어 주고자 했는데, 이 책은 이러한 분야의 고전이라 할 수 있 다. Fraleigh는 이 저서를 통해 스포츠의 도덕적 성격을 분석적으로 설명하려는 것 이상을 시도했는데, 스포츠선 수, 코치 등 스포츠인들이 스포츠에 참여함으로써 갖게 되 는 의무 체계에 관한 매우 명확한 규범적 비전을 제시했 다. 이러한 의미에서 Fraleigh는 스포츠 참여자들의 의무 에 대해 설명했을 뿐 아니라 '좋은' 스포츠란 어떠해야하 는지 설명했다. 따라서 이 책은 의무론적 관심사와 목적 론적 관심사를 모두 구현하고 있다. 무엇보다 이 책의 중 요성은 스포츠경기의 성격에 따라 합리적으로 세워진 의 무를 조직적이고 실용적으로 적용한 데 있다(McNamee, 2017).

『스포츠에서 올바른 행동: 참가자를 위한 윤리(Right Actions in Sport: Ethics for Contestants』(1984)의 출판 직후 스포츠윤리학에 관한 두 번째 고전이라 할 수 있는 Robert Simon의『스포츠와 사회적 가치들 Sports and Social Values)』(1985)가 출판되었다. Fraleigh의 혁신적 책처럼, Simon은 당시 이 분야의 유일한 학술지 인 스포츠철학 저널 (The Journal of the Philosophy of Sport)을 지배하던 경쟁, 게임, 스포츠에 관한 단순한 개 념적 분석을 넘어 개념적 분석과 규범적 분석을 결합시키 고자 했다. Simon의 책은 이후 최근까지도 수정판이 출 간되고 있지만, 핵심구성과 메시지는 그대로다. Simon은 법적, 정치적 계약주의 이론가들을 빌려 스포츠경기는 "탁 월함을 향한 상호 추구(A mutual quest for athletic $\mathrm{ex}^{-}$ cellence)"라고 주장한다. 이 주장은 스포츠윤리학뿐 아 니라 스포츠철학에서도 큰 영향력을 행사해왔다. Simon 의 저서는 스포츠철학계에서 평이 좋았음에도 불구하고 큰 변화를 이끌어내지 못했다(McNamee, 2017). 아마도 이 책의 철학적 난해함과 이 주제를 가르칠 자격을 갖춘 이들이 상대적으로 희소했기 때문일 것이다.

1994년, Angela Lumpkin, Sharon Stoll, Jennifer Beller는 『스포츠윤리: 페어플레이 적용(Sport Ethics: Applications for Fair Play)』라는 저서를 출판했고, 명시 적으로 미국 학부 시장을 겨낭한 이 책은 큰 성공을 누렸다. 그래도 역시나 1998년 Mike McNamee와 Jim Parry가 영국서 낸 편저『윤리와 스포츠(Ethics and Sports)』의 출판이후 Fraleigh와 Simon의 저서들로부터 시작된 스 포츠윤리학의 학술적 작업이 대폭 강화되었다. Fraleigh 와 Simon의 책들과 달리, 이 편저는 이론적으로, 그리고 문화지리적으로 다양했으며, 전 세계 스포츠철학자들의 스포츠윤리에 관한 글을 담았다. 편저다보니 주제 면에서 다양했고 스포츠윤리학이 논할 수 있는 다양한 이슈들을 보여줄 수 있었다. 비평적으로도 성공적이라, 새로운 책 시 리즈가 나오기 시작했으며 그 시리즈에서 나온 책이 서른 권에 이른다. 이 책이 끼친 또 다른 영향력은 영국과 유럽 에서 학부와 대학원에 스포츠윤리와 관련된 교과목들이 만들어졌다는 것이다(Ryall, 2016). 나아가 스포츠윤리학 분야의 굳건함을 보여주는 국제적 선집도 이후 여러 권 출판되었다(Boxill, 2003; McNamee, 2010; Morgan, 2018). 2000년도에 들어서며 스포츠윤리학은 1년에 네 번 출판되는 ${ }^{\circledR S p o r t, ~ E t h i c s ~ a n d ~ P h i l o s o p h y(2007) 』 ㅇ ㅘ ~ 1 ㄴ ㅕ ㄴ ~}$ 에 두 번 영어와 스페인어로 출판되는 ${ }^{\circledR}$ Fair Play Journal of Sport Philosophy, Ethics and Law(2013)』 학술지로 그 영역을 확대해나갔다.

1980년대 중반과 1990년대 사이 미국 스포츠철학은 지적 측면에서나 제도적 측면에서 다소 침체기를 겪고 있 었다(McNamee, 2017). 이 당시 미국 스포츠는 상업화가 가속화되고 있었고, 이로 인해 많은 윤리적 이슈들을 생 산해내고 있었다. 이때 스포츠철학의 틈을 비집고 나와 학문적으로 급성장했던 분야가 스포츠윤리학이다. 요컨 대, 스포츠윤리학이 스포츠철학을 살렸다고 할 수는 없지 만 매우 절실했던 산소 공급을 해주었다고는 볼 수 있다.

국내에서 스포츠윤리 연구가 활성화된 것은 비교적 최 근의 일인데, 2000 년대 이후 승부조작, 도핑, 관중폭력뿐 만 아니라 스포츠선수들의 일탈행위가 사회적 문제로 대 
두되면서 스포츠윤리 연구에 대한 사회적 요구와 필요성 이 크게 증대되었다. Kim, Kim, \& Park(2017)은 1992 년 창간호부터 2016년 12월까지 한국체육철학회의 학술 지에 게재된 모든 논문을 검토하여 스포츠윤리 연구동향 을 분석하였는데, 지난 24 년간 게재된 1,137 편의 논문 중 스포츠윤리 연구영역에 해당하는 논문은 144 편으로 전체 게재된 논문의 $12.6 \%$ 를 차지하고 있는 것으로 나타 났다. 특히, 1992년부터 1999년까지 총 게재 논문 173편 중 스포츠윤리 영역의 논문은 12 편으로 비율이 $6.9 \%$ 에 불과하였으나, 2000년부터 2016년까지는 964편 중 132 편, 비율은 $13.6 \%$ 로 스포츠윤리에 관한 연구가 최근 10 년간 크게 증가하였음을 확인할 수 있었다. 2000년 이후 의 스포츠윤리 관련 연구들을 살펴보면, 스포츠윤리의 개 념정의나 단순한 윤리적 담론에서 벗어나 (성)폭력, 도핑, 불평등, 승부조작, 동물윤리 등 스포츠 상황에서 발생하고 있는 실제 문제들을 다루는 연구들이 조금씩 증가하고 있 다(Kim, Kim, \& Park, 2017).

하지만 이처럼 스포츠에서 발생하는 윤리적 이슈와 쟁 점을 다루고 있는 연구논문은 급증하고 있지만, 대부분의 연구들이 이슈에 대해 체계적이고 과학적으로 설명할 수 있는 이론적 기반과 연구방법 측면에서는 부족한 점이 있 다. 즉, 스포츠윤리 이슈를 다루고 있는 논문들이 넘쳐나 고 있지만 정작 그것을 연구하는 학문 집단의 구성원들이 공통적으로 이해하고 공유하는 개념적 틀이라 할 수 있는 학문적 패러다임과 정체성에 관한 연구물은 지금까지 거 의 없다. 아주 소수이지만, 스포츠윤리 자체에 대한 메타 철학적 반성을 통해 스포츠윤리를 정초하려고 시도한 논 문은 몇몇 있다.

Lee(2006)는 스포츠윤리를 형이상학적, 철학적 과정 을 통해서 그 학문영역을 정초하려고 시도하였지만, 단지 의무론과 결과론으로 스포츠윤리 연구의 이론적 기반을 설명하려는 한계를 갖고 있다. Kim \& Goo(2007)는 스 포츠윤리에 관한 명확한 개념과 이론적 근거를 정립하지 못하고 있음을 지적하며 스포츠윤리 문제를 극복하기 위 한 도덕적 기준과 가치를 정초하고 스포츠윤리의 실천과 제를 제시하였다. $\operatorname{Kim}(2013)$ 의 논문은 스포츠윤리의 학 문적 특징을 개괄함으로써 스포츠윤리 담론이 갖는 한계 와 이를 극복하기 위한 과제를 제시하였다. 하지만 이 소 수의 논문들마저도 스포츠윤리학이란 용어를 차용하고는 있으나 스포츠윤리학이 무엇이고, 구체적인 연구대상은 무엇이며, 그 대상을 학술적으로 연구하기 위한 이론은 무
엇인지와 같은 스포츠윤리학의 학문적 정체성과 관련된 근본적인 질문들에 대해서는 구체적인 답을 제시하고 있 지 않다.

해외에서는 스포츠윤리학의 이론적 틀을 다루는 학술 논문 뿐만 아니라, 출판된 스포츠윤리학 저서 또는 편저 도 수십 권에 달하나, 아직 국내에서는 학문적 체계를 갖 추고 있는 스포츠윤리학 저서가 거의 없고, 스포츠윤리 연구를 위한 이론적 틀에 대한 정보와 연구가 미흡하기 때문에 저서 편찬 작업이 활성화되지도 않고 있는 실정이 다. 따라서 향후 해외 저명 스포츠윤리학자들의 저서와 연구물에서 기술되는 이론, 그들이 활용하는 연구방법, 그 리고 연구들의 실제 응용에 대한 고찰을 통하여 한국 스 포츠윤리학이 연구해야 할 지향점을 찾고, 스포츠윤리학 의 연구영역과 연구방법론, 그리고 그 근간이 되는 스포 츠이론을 도출하는 스포츠윤리학의 학문적 체계 정립을 위한 연구가 활성화되어야 할 것이다.

\section{스포츠윤리학의 방법론과 이론적 틀}

스포츠윤리학에서 발견되는 지배적인 윤리이론들은 대 개 약간의 수정을 거쳐 적용되어왔다. Fraleigh의 스포츠 윤리 연구는 일반적인 윤리이론을 받아들여 스포츠와 섞은 후에 행 동을 이끌 규범적 가이드라인을 추론해낸 것이 대 부분이었다. 주로 의무론과 목적론을 결합한 것이었지만, 정확히 그 이론들이 어떻게 결합된 것인지에 관한 정교한 방법론적 세부사항은 나와 있지 않다(McNamee, 2017). 노르웨이 철학자 Sigmund Loland(2002)는 Rawls의 정 의론과 공리주의 철학을 결합해 페어플레이의 규범에 관한 스포츠 참여자들의 합리적 동의를 극대화할 것을 시도했다. Loland의 저서, ${ }^{『}$ 스포츠에서 페어플레이: 도덕적 규범 시 스템(Fair Play in Sport: A Moral Norm System』 (2002) 를 분석해보면, 그는 자유주의 정치철학자 John Ralws의 고전 『정의론(A Theory of Justice)』(1971)로부터 큰 영 감을 받은 것을 알 수 있다. Loland와 Fraleigh 둘 모두 스포츠에 참여하는 모든 경쟁자들을 규범이나 행동의 가이 드라인에 구속시킬 일종의 건축구조를 개발하려 했다. 많 은 스포츠철학자들에게 이건 지나치게 합리적이라는 인상 을 주었다. 몇몇 학자들(McNamee, 2017; Morgan, 2017, Russell, 2018)은 이 둘의 기저에 깔린 보편주의가 인간 주 체, 문화적 차이, 그리고 스포츠제도의 막강한 영향력을 간 과한다고 주장했다. 
2000년대에 들어서면서 스포츠윤리 연구에 활기를 불 어넣은 두 명의 스웨덴 출신의 철학자들이 등장한다. Claudio Tamburrini (1998, 2000)와 Torbjörn Tännsjö (1998, 2000)는 그들의 전문 분야인 도덕철학과 정치철 학을 토대로 결과주의 (consequentialism)를 엄격히 적용 함으로써 스포츠의 기존 윤리적 사상에 도전하며 큰 흥미 와 관심을 불러일으켰다. Loland는 공리주의적 사고와 롤 스식 정의 접근을 합쳐 스포츠에 적용했지만, Tamburrini 와 Tännsjö는 널리 통용되는 스포츠규범에 도전하는 연구 들을 각각 출판하였다. 이 두 학자들은 주로 보수주의를 공 격하고, 논쟁적인 주제를 자유주의와 공리주의 입장에서 옹호하고, 간과되어온 스포츠윤리 이론을 홍보하며 스포 츠윤리학 분야에 신선한 자극을 가져왔다. 다만, 이 두 학 자의 공리주의에 대한 권위와 전문성에도 불구하고 스스 로의 논쟁적인 입장을 옹호하는 실증적 증거가 거의 없다 는 것이, 실증에 근거해야하는 윤리학에 있어 큰 약점으로 지적되어진다(McNamee, 2017; Moller, 2009; Radford, 1998; Russell, 2005).

아마도 스포츠윤리학에서 가장 많이 활용되는 접근방 법은 '덕 윤리학' 분야의 이론적 틀이라 할 수 있다(Arnold, 1997; Feezell, 2004; Gough, 1995; Holowchack \& Reid, 2011; McNamee, 2008). 대부분 아리스토텔레스의 이 론이거나, 또는 Martha Nussbaum, Edmund Pincoffs, 그 리고 Alasdair MacIntyre처럼 아리스토텔레스의 영향을 많 이 받은 현대 철학자들의 이론에 기초하고 있다. MacIntyre 는 그의 유명한 저서 『미덕 그 이후(After Virtue)』(1981) 에서 필연적으로 사회적일 수밖에 없는 맥락 안에서 미덕 이 이해되어야 한다고 밝히며, 미덕은 올바른 행동의 원칙 이 아닌 선한 삶을 살려는 선한 사람들의 특정한 기질이라 고 설파한다. Feezell(2013), Simon(1991) 등과 같은 일 부 학자들은 사회적 관습과 구성적 미덕에 대한 MacIntyre 의 구체적 주장을 언급하지 않고 일반적인 이론만 이용해 왔다. Arnold(1997), Dombrowski(2009), McNamee (2008), Morgan(2017), Reid(2012)와 같은 또 다른 학 자들은 스포츠를 사회적 관습, 탁월함, 협동의 미덕이라 는 초자아적 규범에 기반을 두고 스포츠에 내재한 만족감 과 가치라는 내재적 선을 추구하는 사회적 관습이라고 해 석해왔다. 학자들 간 차이점들에도 불구하고 스포츠의 외 재적 가치라고 불리는 돈, 명예, 매스컴 등 외부의 것들이 스포츠를 분열시키고 있다는 공통의 걱정거리를 가졌다. 물론 그 정도나 정확한 경제적 병리현상에 대해서는 같은
의견은 아니었다. 외재적 선(goods)을 강조하는 것이 스 포츠를 부패시킬 수 있다는 생각이 폭넓은 지지를 받음에 도 불구하고, 스포츠에 관련된 내재적 선을 어떻게 식별 할 것인지에 관한 의문이 덕론에 기반을 두고 있는 스포 츠윤리학자들의 한계로 지적되어 왔다(Morgan, 2006).

하나의 학문 분야로서 스포츠윤리학의 정체성은 연구 주제에 관해 체계적이고 과학적으로 설명할 수 있는 이론 적 틀을 제시하느냐에 달려있다. 스포츠윤리학은 윤리학을 모(母)학문으로 두고 있는 응용윤리 중 하나이다. 이는 여 타 다른 응용윤리 분야도 그렇듯이, 앞서 언급한 것처럼 대 부분 윤리학에서 개발된 이론들을 스포츠에 가져다 사용 하거나 응용하여 사용하고 있다. 물론 스포츠윤리학 분야 에서 자체적으로 개발된 형식주의(formalism), 내재주의 (internalism), 관습주의 (conventionalism), 제도론(institutional theory) 등과 같은 스포츠의 의미에 관한 통 찰력을 심화시키는 고유한 이론들도 존재한다.

\section{국내 스포츠윤리학의 과제와 전망}

\section{과제}

'스포츠윤리학자'라고 불릴 수 있는 전문가는 어떤 지 식과 기술을 가진 사람일까? 조금 더 노골적으로 표현하 면, '스포츠윤리학자'라고 부를 수 있는 특정 영역의 전문 가가 존재는 하는 걸까? 이러한 의문의 이유는, 후기 근대 주의 (modernity)에 있어 유일한 윤리적 관점은 주관주의 (subjectivism)이기 때문이다. 즉, 스포츠에 관한 윤리적 이슈는 스포츠철학자나 스포츠윤리학자가 아니더라도 누 구나 접근하고 다룰 수 있는 이슈라는 것이다. 그렇다면 스포츠윤리학자의 권위는 어떠한 전문성에서 나오는 것 일까? 이러한 물음에 대해 Kretchmar(1998)는, 스포츠 윤리학자는 스포츠의 본질에 대한 정교한 이해가 필수적 으로 선행되어야 한다고 주장한다. 스포츠의 본질에 대한 이해 없이 선수들의 행동을 이해하는 것은 매우 어렵기 때문이다. 이와 더불어 스포츠윤리학자는 경기의 규칙들 에 대해 철저히 이해해야 하는데, 구성적 규칙과 규제적 규칙의 분명한 차이, 널리 통용되는 관습적 규칙들을 이해 하는 것도 필수다. 또한 Kretchmar(1998)는 스포츠윤 리학자는 스포츠 행위 방식을 지시하고 통제하는 규범들 에 대해서도 충분한 지식을 지니고, 특정 행위의 규범적 
가치를 고찰할 수 있는 능력을 가져야 하는데, 이러한 능 력을 가지려면 규칙이 허락하거나 불허하는 공식적/비공 식적 합의에 대해서도 익숙해야 한다고 주장한다. 하지만 이러한 Kretchmar의 조건들에 비춰본다면, 스포츠 애호 가라면 위에 언급한 지식들은 이미 대개 갖고 있는 것 아 닌가? 오히려 평생 스포츠를 한 선수나 코치들이 더 전문 가라고 할 수 있는 건 아닐까?

그렇다면 스포츠윤리학자가 가져야 할 지식은 스포츠 윤리를 전공하지 않는 다른 학자들이 가진 기술이나 지식 보다 많거나 적어도 부분적으로 달라야한다고 할 수 있 다. 그러한 지식은 스포츠의 개념적 성격에 관한 규범적 이고 윤리학적인 이해이다. 여기서 규범적, 윤리학적 이 해라는 것은 스포츠에서 해서는 안 되는 행위와 해도 되 는 행위를 단순히 나열하고 구분짓는 가치판단을 말하는 것이 아니다. 스포츠윤리학자의 지식은 여기에 그치는 것 이 아니라, 그러한 가치판단의 기준과 근거가 무엇인지를 설명할 수 있어야 한다. 즉, 스포츠상황 속에서 직면하는 윤리적 판단 혹은 행위의 원리나 근거를 마련하기 위해 도덕의 본질적인 문제에 대해 탐구할 수 있는 역량이 바 로 스포츠윤리학자가 갖춰야 하는 전문성이다. 예를 들 어, 스포츠에서 도핑은 공정성에 어긋나기 때문에 비윤리 적이라는 판단은 누구나 내릴 수 있는 가치판단이다. 하 지만 스포츠윤리학자는 도핑을 윤리적인 시험대에 올려 놓고 왜 공정성에 어긋나고, 어떤 윤리적 원리에 위배되 는지, 그리고 금지시킬 납득할 만한 당위성을 가지는지를 윤리학적으로 고찰하고 설명할 수 있어야 한다. 또한 스 포츠윤리학자는 형식주의, 내재주의, 관습주의, 제도론 등과 같은 스포츠의 의미에 관한 통찰력을 심화시키는 다 양한 이론도 익숙하게 다룰 수 있어야 한다.

아직까지 스포츠윤리학자는 스포츠철학자와 다를 바 없다. $\operatorname{Kim}(2013)$ 이 주장하듯, 가치판단의 근거에 대한 탐구와 고찰은 철학의 영역에 속하기에, 스포츠 속 행위 와 현상의 가치판단에 대한 철학적 논의인 스포츠윤리학 은 근본적으로 스포츠철학과 다름 아니라고 할 수 있다. 그런데 스포츠철학자 모두가 반드시 스포츠에 접근하는 깊고도 체계적인 윤리학적 지식을 가질 필요는 없다. 하 지만 이 지식은 스포츠윤리학자에게는 필수다. 왜냐하면 스포츠윤리학자는 스포츠에 내재된 도덕적 한계, 전략적 파울, 스포츠맨십, 스포츠 속 속임수, 경쟁과 페어플레이 등에 대해 개념적으로 그리고 규범적으로 고찰해야하기 때문이다. 또한 스포츠윤리학자는 의무론(Deontology),
결과주의(Consequentialism), 덕론(Virtue Theory), 계 약론(Contractarianism), 자유주의(Liberalism), 온정주 의(Paternalism) 등 다양한 윤리이론에 대한 이해를 바탕 으로 도핑뿐만 아니라 스포츠에서 동물의 권리, 동성애, 평등, 인권 및 환경윤리에 이르기까지 폭 넓은 주제에 관 한 윤리적 담론을 형성할 수 있어야 한다. 물론 McNamee (2017)가 주장하듯, 스포츠윤리학자에게 무결점의 기술 적 해결이나 이론적 중립성을 기대해서는 안 된다. 스포 츠윤리학자는 변증법적 추론, 도덕적 추론, 논증적인 추 론 등의 논쟁 전략들을 무기로 삼아 스포츠가 당면한 윤 리적 갈등과 쟁점들에 관해 분석함으로써 문제점을 제기 하고 해결을 위한 이론적 토대와 정책적 방안을 제시할 수 있어야 한다. 이것이 바로 스포츠윤리학자가 가진 지 식의 토대이자 스포츠윤리학자가 권위를 주장할 근거가 되는 이론적이고 실천적인 지식이다.

이처럼 스포츠윤리학이 권위와 전문성을 갖기 위해서 는 무엇보다 선행되어야 할 과제가 있다. 바로 스포츠윤 리의 학문적 정체성 정립이다. 어떤 것이 독립된 학문으 로 성립하기 위해서는 그 학문 집단의 구성원들이 공통적 으로 이해하고 공유하는 개념적 틀이라 할 수 있는 패러 다임이 있어야 한다(Ryu, Go \& Yang, 2014). 즉, 독자 적이고 고유한 연구주제가 있고, 개념적 경계가 뚜렷해야 하며, 특히 연구주제를 학문적으로 설명하고 논증하기 위 한 이론이 있어야 하며, 학문적 공동체로서의 관련 학회 가 구성되어 있어야 한다. 최근 스포츠윤리에 대한 사회 적 관심과 필요성이 증대하면서 스포츠윤리 연구의 고유 한 주제들이 형성되고 있다. 하지만 문제는 연구주제를 체계적이고 학문적으로 설명할 수 있는 이론들이 아직 국 내에서는 제대로 정립되어 있지 않으며, 이로 인해 다른 학문(스포츠사회학, 스포츠교육학 등)과의 개념적 경계 도 뚜렷하지 않다는 것이다. 그렇다 보니, "스포츠윤리를 누가 가르칠 수 있느냐(교육주체)"는 질문에, “누구나 가 르칠 수 있다”라는 답변이 나오기까지 한다. 그러나 스포 츠윤리학이라는 학문적 패러다임을 가지고 공동연구를 할 수 있는 한국체육철학회라는 학회가 이미 활발히 운영 되고 있다. 따라서 학회의 학자들 간 연구의 교류를 통하 여 스포츠윤리학이 하나의 학문으로 그 정체성을 정립할 수 있는 충분한 가능성은 지니고 있다.

체육계의 스포츠윤리 확립을 위한 제도적 장치를 마련 하고 스포츠윤리를 교육하기 위한 방향과 체계를 모색하 기 위해서는 스포츠윤리학을 학문적으로 정초하는 것이 
우선적으로 필요하다. 따라서 미국과 영국을 중심으로 정 립되어 온 해외 스포츠윤리학의 학문적 체계에 대한 분석 을 토대로 국내 스포츠윤리 연구를 위한 주제, 이론, 방법 론에 관한 $\mathrm{DB}$ 를 구축하는 작업이 절실하다. 또한 연구주 제를 학문적으로 분석하고 설명하는 데 근간이 되는 이론 적 틀과 접근방법을 주제별·기능별로 정리하여 보급함으 로써 스포츠윤리학의 학문적 패러다임을 정립하는 하는 것이 한국 스포츠윤리학이 당면한 과제일 것이다.

\section{전망}

스포츠윤리학의 미래는 스포츠윤리학의 과거와 현재 를 비추어 볼 때 그 전망을 예측할 수 있다. 지금까지의 스포츠윤리학 연구를 살펴보면, 불변성과 변동성을 동시 에 유지하고 있다. 불변성은 스포츠윤리학이 지향하는 근 본적인 질문, 즉 스포츠란 무엇이며, 어떻게 행해져야 하 고, 어떻게 가르치고 배울 것인가 등 스포츠의 본질과 목 적에 관한 탐구이며, 변동성은 그 탐구의 방식의 변화를 의미한다. 그 방식이 과거에는 현상학적 것이 주류를 이 루었다면, 현재에는 비판적이고 경험적이며 실증적 데이 터에 의존하는 경향이, 그리고 미래에는 보다 융합적인 경향이 될 것이라 예측한다.

최근 연구 흐름은 융·복합이 각광을 받고 있다. 학제간 연구, 즉 연구 영역에 있어 독립적인 연구가 아닌 복합적 연구인 하이브리드 연구가 요구되고 있다. 스포츠윤리 관 련 주제들은 그 양상이 다소 복잡하고 복합적이기 때문 에, 여타 다른 응용윤리 분야도 그렇듯이 타학문과 상호 협력 하는 연구가 효율적일 것이다. 국내 스포츠윤리와 관련된 연구는 대부분 독립적 연구로 수행되어 왔지만, 앞으로의 스포츠윤리학은 인류학, 심리학, 사회학, 정치 학, 법학, 윤리학, 미학, 의학, 공학의 이론과 지식들을 적극 수용하고 그들의 접근방법을 복합적으로 활용해야 될 것이다.

특히 응용윤리학의 일부 분야에서 윤리학과 법학이 함 께 연구되고 있다는 사실이 주목할 만하다. 의료윤리, 공 학윤리, 환경윤리 등에서 특히 그렇다. 스포츠에서도 이 둘의 결합에는 분명한 이점이 있다. 무엇보다 스포츠윤리 에 관한 논의가 더 광범위한 호응을 얻을 수 있다. 스포츠 윤리학자가 지적하는 윤리적 요점이 법적인 맥락에서 이 루어질 때, 정부 스포츠기관 및 체육단체는 더 귀를 기울 일 것이며, 이것이 실제 행정적, 제도적 변화로 이어질 가
능성이 높다. 또한 스포츠법학자들 역시 스포츠윤리학자 의 학문적 결과로부터 원칙적으로는 득을 볼 수 있다. '원 칙적으로는' 이라고 말하는 까닭은 법학의 연장도구들이 철학과 그리 다르지 않기 때문이다(McNamee, 2017). 최 소한 이 두 분야 사이에 시너지가 발생한다고 기대해 볼 수 있는데, 현재 상업화된 스포츠, 특히 프로스포츠에서 는 이미 밀접한 관련을 맺으며 자라나고 있는 실정이다.

요컨대, 향후 스포츠윤리학은 다양한 학문과 연구방법 을 종합하는 융합적인 접근방법으로 나아갈 것으로 예측 되며, 또한 앞으로 스포츠윤리학은 이론(theory)과 실천 (practice)이 긴밀하게 연결된 학문으로서 나아가야 한다. 이러한 융합적 지식이 결합하고 여기에 철학적 예리함이 더해져 스포츠윤리학자가 실용적 지혜를 계발할 수 있는 것이며, 이러한 지혜는 스포츠의 운영, 관리, 교육, 보급. 확산, 경기조직, 체육정책 수립 같은 스포츠의 일상적 영 역에 권위 있는 간섭과 조언을 제공할 수 있을 것이다. 물 론 학문의 미래를 예측하는 건 쉽지 않다. 하나 분명한 것 은, 지금 스포츠윤리학은 초기지만 융성하고 있으며, 실 용적이고 장기적인 미래의 신호를 보이고 있다는 것이다.

\section{결 론}

오늘날 고도의 상업화된 스포츠는 경쟁을 통한 승리와 기록을 최고의 가치로 삼는 냉혹한 승부의 세계가 되었 다. 자본주의가 지배하는 20세기에 들어오면서 스포츠는 도전이나 극기 같은 순수한 정신적 가치의 발현이라기보 다 올림픽, FIFA 월드컵, 세계육상선수권대회 등 "메가 스포츠이벤트"(Preuss, 2007; Hiller, 2000)로 대표되 는 소비주의와 오락의 최전방에 서게 되었다. 그 결과 승 부조작과 담합, 금지약물의 복용, 심판매수, 부정 장비사 용, 선수 (성)폭행, 파벌, 경기장 관중 폭력사태, 무분별 한 스포츠시설 확충으로 인한 환경오염 등 수많은 문제점 들을 가지게 되었다. 승리와 기록에만 치중하는 오늘날의 스포츠를 비판하고 반성할 수 있는 시각을 확보하고 과학 과 자본의 논리에 의해 빚어지는 스포츠계의 제문제에 대 해 성찰과 통찰을 위한 스포츠윤리학의 정립이 절실히 요 구되는 시점이다. 이러한 시점에서 스포츠윤리학이 과연 무엇을 하는 학문이며, 어떻게 해야 하는지, 그리고 과연 학문적으로 어떠한 위치에 있으며 어떻게 나아가야 하는 지에 대한 심도 있는 논의는 스포츠윤리학의 학문적 발전 
에 있어 무엇보다 중요한 일이다.

스포츠윤리학의 정체성은 한편으로는 이것이 무엇인 가에 대한 탐구이며, 다른 한편으로는 이것이 왜 필요하 며, 어떻게 되어야 할지에 대한 탐구이기도 하다. 전자는 스포츠윤리학이 어디서, 어떻게 등장하여 현재 어떠한 위 치에 와 있는가, 즉 스포츠윤리학의 과거와 현재를 뜻하 며, 후자는 스포츠윤리학의 의의와 과제, 즉 스포츠윤리 학의 미래와 관련된다. 이에 본고는 먼저 스포츠윤리학의 등장배경인 스포츠철학의 역사를 살펴본 후, 국내외 스포 츠윤리학의 간략한 역사와 스포츠윤리학의 연구범위와 주요 이론을 고찰하였고, 이를 토대로 국내 스포츠윤리학 의 과제와 전망을 제시해보았다.

어떤 학문이 독자적인 학문 분야로서 그 정체성을 인정 받으려면 그 학문의 패러다임이 확립되어 있어야 한다. 미국의 유명한 철학자 Thomas Kuhn(1996)은 그의 저 서『과학혁명의 구조(The Structure of Scientific Revolutions)』에서 '패러다임(paradigm)'이라는 개념을 제시 하며 "한 시대 사람들의 견해나 사고를 지배하고 있는 이 론적 틀이나 개념의 집합체”로 정의하였다. Kuhn(1996) 에 따르면, 어떤 학문이 하나의 정상학문으로서 위치하기 위해서는 그 학문을 전공하는 학자들 간 연구의 기초가 되는 기준, 이론, 응용, 주제 및 방법을 총칭하는 패러다임 을 공유해야 한다는 것이다. 즉, 어떤 학문이 패러다임을 갖지 못할 때에는 무엇을 연구해야 하고, 어떻게 연구해 야 하며, 어떤 이론을 정립할 수 있는지 등과 관련된 기본 적인 문제에 대한 논란이 발생할 뿐만 아니라 학문적 발 전도 기대하기 어렵다는 것이다(Ryu, Go \& Yang, 2014). 따라서 스포츠윤리학이 하나의 독자적 영역을 갖는 정 상학문이 되기 위해서는 스포츠윤리 연구자들 간 비슷한 시각과 비슷한 관점으로 이해되는 연구주제 및 연구범위 가 구분되고, 그것을 연구하는 방법론, 그리고 과학적이 고 체계적으로 연구주제를 설명할 수 있는 이론이 개발되 고 제시되어야 한다. 이것이 국내 스포츠윤리 연구자들이 당면한 과제이다. 하나의 학문이 성립하고 성공적으로 발 전하는 것은 수많은 학자들의 연구와 실제 현장의 실천적 성과, 다양하고 현실적인 정책적·제도적 뒷받침, 그리고 그 학문의 연구내용과 방법론에 대한 지속적인 논의와 합 의들이 종합적으로 집적되었을 때 가능한 일이다 $(\mathrm{Sim}$, 2013). 스포츠윤리학도 다양한 학문적 전통을 가진 학자 들이 '스포츠윤리'라는 주제에 대해 관심을 가지고 연구하 며, 연구자간 학술적 교류를 통해 이론적 기반과 연구방
법의 타당성을 확보하고, 그 연구결과가 교육을 통해 보 급·확산되어 스포츠의 발전을 위해 올바른 방향을 제시하 는 나침반의 역할을 할 수 있을 때, 그 학문적 체계와 위 상을 정립하고 스포츠윤리학자의 전문성도 제고할 수 있 을 것이다.

\section{참고문헌}

Andrieu, B. (2014). The Birth of the Philosophy of Sport in France 1950-1980. Part 1: from Ulamm to Rauch through Vigarello. Sport, Ethics, and Philosophy, 8(1), 32-43.

Arnold, P. (1997). Sport, Ethics and Education. London: Bloomsbury.

Best, D. (1978). Philosophy and Human Movement. London: Lepus.

Boxill, J. (2003). Sports Ethics: An Anthology. Oxford: Blackwell.

DaCosta, L. (2006). A Never-Ending Story: The Philosophical Controversy over Olympism. Journal of the Philosophy of Sport, 33(2), 157-173.

Dombrowski, D. (2009). Contemporary Athletics and Ancient Greek Ideas. Chicago, IL: University of Chicago Press.

Feezell, R. (2004). Sport, Play and Ethical Reflection. Urbana, IL: University of Illinois Press.

Feezell, R. (2013). Sport, Philosophy and Good Lives. Lincoln, NE: University of Nebraska Press.

Fraleigh, W. (1983). The Philosophic Society for the Study of Sport. Journal of the Philosophy of Sport, X, 3-7.

Fraleigh, W. (1984). Right Action in Sport: Ethics for Contestants. Champaign, IL: Human Kinetics.

Gough, R. (1995). On Reaching First Base with a 'Science' of Moral Development in Sport: Problem with Scientific Objectivity and Reductivism. Journal of the Philosophy of Sport, 22(1), 11-25.

Hata, T., \& Sekine, M. (2010). Philosophy of Sport and Physical Education in Japan. Its History, Characteristics and Prospects. Journal of the Philosophy of Sport, 37(2), 215-224.

Hiller, H. (2000). Mega-events, Urban Boosterism and Growth Strategies: An Analysis of the Objectives and Legitimations of the Cape Town Olympic Bid. International Journal of Urban and Regional Research, 24(2), 449-58.

Holowchak, M., \& Reid, H. (2011). Aretism. New York: Lexington. Holt, R. (1989). Sport and the British: A Modern History. Oxford: Clarendon. 
Kang, S. M. (2013). Sport Paradigm: Trends and Issues; The Philosophy and Ethics of Sport in North America and the United Kingdom. Journal of the Korean Society for the Philosophy of Sport, Dance \& Martial Arts, 21(2), 97-113.

Kim, D. K., \& Goo, K. B. (2007). Sport Ethics: Foundation and Guidelines. The Korean Journal of Physical Education, 46(5), 105-117

Kim, J. H. (2013). A Study on the Discussion in Sport Ethics. Journal of the Korean Society for the Philosophy of Sport, Dance \& Martial Arts, 21(1), 97-114.

Kim, J. H., Kim, J. H., \& Park, S. J. (2017). Research Trends in Sport Ethics: An Analysis of the Journal of Korean Philosophic Society for Sport and Dance. Journal of the Korean Society for the Philosophy of Sport, Dance \& Martial Arts, 25(3), 59-77.

Kretchmar, S. (1983). Ethics and Sport: An Overview. Journal of the Philosophy of Sport, 10, 21-32.

Kretchmar, S. (1998). Soft Metaphysics: A Precursor to Good Sports Ethics. In M. McNamee \& J. Parry (Eds.) Ethics and Sport (pp. 19-34). Abingdon: Routledge.

Kuhn, T. (1996). The Structure of Scientific Revolutions (3rd Ed.). Chicago: University of Chicago Press.

Lee, H. J. (2002). A Study on History of Sport Philosophy in Korea. Journal of the Korean Society for the Philosophy of Sport, Dance \& Martial Arts, 10(2), 319-353.

Lee, J. W. (2006). Sport Philosophy: How Is Sport Ethics Possible? Journal of the Korean Society for the Philosophy of Sport, Dance \& Martial Arts, 14(1), 1-18.

Loland, S. (2002). Fair Play in Sport: A Moral Norm System. London: Routledge.

Lumpkin, A., Stoll, S., \& Beller, J. (1994). Sport Ethics: Applications for Fair Play. St. Louis, MO: Mosby.

MacIntyre, A. (1981). After Virtue. London: Duckworth.

Mangan, J. (1981). Athleticism in the Victorian and Edwardian Public School. Cambridge: Cambridge University Press.

Mangan, J. (1987). Manliness and Morality. Manchester: Manchester University Press.

Martinkova, I., \& Parry, J. (2012). Phenomenological Approaches to Sport. Abingdon: Routledge.

McIntosh, P. (1979). Fair Play: Ethics in Sport and Education. London: Heinemann.

McLaughlin, D., \& Torres, C. (2011). A Moral Justification for a More Inclusive Olympic Program. Olympika, 20, 55-78.

McNamee. M. (2006). Olympism, Eurocentricity, and Transcultural Virtues. Journal of the Philosophy of Sport, 33(2), 174-187.
McNamee. M. (2008). Sports, Virtues and Vices: Morality Plays. Abingdon: Routledge.

McNamee. M. (2010). The Ethics of Sport: A Reader. Abingdon: Routledge.

McNamee, M. (2017). Ethics and Sport. In M. McNamee \& W. Morgan (Eds.), Routledge Handbook of the Philosophy of Sport (pp. 131-141). New York, NY: Routledge.

McNamee, M., \& Morgan, W. (2017). A Historical Introduction to the Philosophy of Sport. In M. McNamee \& W. Morgan (Eds.), Routledge Handbook of the Philosophy of Sport (pp. 1-8). New York, NY: Routledge.

McNamee, M., \& Parry, J. (Eds.) (1998). Ethics and Sport. Abingdon: Roudledge.

Metheny, E. (1968). Movement and Meaning. New York: McGrawHill.

Moller, V. (2009). The Ethics of Doping and Anti-doping: Redeeming the Soul of Sport? Abingdon: Routledge.

Morgan, W. (2006). Why Sports Morally Matter. Abingdon: Routldege.

Morgan, W. (2017). Conventionalism and Sport. In M. McNamee \& W. Morgan (Eds.), Routledge Handbook of the Philosophy of Sport (pp. 35-52). New York, NY: Routledge.

Morgan, W. (Ed.) (2018). Ethics in Sport (3rd ed.). Champaign, IL: Human Kinetics.

Park, S. J. (2014). Theoretical Foundations on Sport Ethics. Journal of the Korean Society for the Philosophy of Sport, Dance \& Martial Arts, 22(3), 77-97.

Park, S. J. (2016). A Program Development and Application on Educating Sport Ethics. The Korean Journal of Physical Education, 53(1), 37-47.

Paryy, J. (2006). Sport and Olympism: Universals and Multiculturalism. Journal of the Philosophy of Sport, 33(2), 188-204.

Preuss, H. (2007). The Conceptualization and Measurement of Mega Sport Event Legacies. Journal of Sport and Tourism, 12(3-4), 207-27.

Radford, C. (1988). Utilitarianism and the Noble Art. Philosophy, 63(243), 63-81.

Rawls, J. (1971). A Theory of Justice. Cambridge: Harvard University Press.

Reid, H. (2012). Athletic Beauty in Classical Greece: A Philosophical View. Journal of the Philosophy of Sport, 39(2), 281-297.

Renson, R. (2009). Fair Play: Its Origins and Meanings in Sport and Society. Kinesiology, 41, 15-18.

Russell, J. (2005). The Value of Dangerous Sport. Journal of the 
Philosophy of Sport, 32(1), 1-19.

Russell, J. (2018). Broad Internalism and the Moral Foundations of Sport. In W. Morgan (Ed.), Ethics in Sport (3rd Ed.) (pp. 77-92). Champaign, IL: Human Kinetics.

Ryall, E. (2016). Philosophy of Sport: Key Questions. New York, NY: Bloomsbury.

Ryu, S. I., Ko, E. B., \& Yang, G. G. (2014). A Study on Identity of Fire Science and Possibility of Convergence Study. Korean Review of Crisis \& Emergency Management, 10(3), 135-147.

Sim, S. H. (2013). A Study for a Discipline Map of Philosophy of Education: Past, Present and Future of Philosophy of Education. The Journal of Korean Educational Idea, 27(3), 241-274.

Simon, R. (1985). Sport and Social Values. Englewood Cliffs, NJ: Prentice-Hall.

Simon, R. (1991). Fair Play: Sport, Values, and Society. Colorado:
Westview.

Slusher, H. (1967). Man, Sport, and Existence: A Critical Analysis. Philadelphia: Lea and Febiger.

Song, H. S. (2015). Research Trends of Sport Philosophy: Focused on the Philosophical Articles in Journal of Korean Philosophic Society for Sport and Dance. Korean Journal of Sport Science, 26(1), 1-14.

Tamburrini, C. (1998). Sport, Fascism and the Market. Journal of the Philosophy of Sport, 25, 35-47.

Tamburrini, C., \& Tännsjö, T. (2000). Values in Sport: Elitism, Nationalism, Gender Equality and the Scientific Manufacture of Winners. London: E \& FN Spon.

Tännsjö, T. (1998). Is our Admiration for Sports Heroes Fascistoid? Journal of the Philosophy of Sport, 25(1), 23-34.

Weiss, P. (1969). Sport: A Philosophical Inquiry. Carbondale, IL: Southern Illinois University Press. 


\section{스포츠윤리학의 역사와 과제, 그리고 전망}

\section{박성주 (국민대학교)}

[목적〕 본고는 하나의 학문으로서 스포츠윤리학의 정체성과 의의를 성찰하는 근본적인 목적을 가지고, 스 포츠윤리학이 어디에서부터 시작되고, 어떻게 성장해 왔으며, 현재 어떠한 위치에 와 있고, 향후 어떻게 나아 갈 것인지, 그리고 나아가야 하는지에 대해 구체적으로 살펴보고자 한다. 〔방법〕 이를 위해, 먼저 스포츠윤리 학의 부모 학문이라 할 수 있는 스포츠철학의 역사를 살펴보고, 둘째, 스포츠철학의 역사적 과정에서 스포츠윤 리학의 등장과 그 배경을 분석하며, 셋째, 스포츠윤리 연구의 주요 방법론과 이론적 틀을 고찰하고, 끝으로 국내 스포츠윤리학의 과제와 전망을 제시하였다. 〔결과〕 향후 스포츠윤리학은 다양한 학문과 연구방법을 종합 하는 융합적인 접근방법으로 나아갈 것으로 예측되며, 또한 앞으로 스포츠윤리학은 이론과 실천이 긴밀하게 연결된 학문으로서 나아가야 한다. 국내 스포츠윤리학이 당면한 과제는 스포츠윤리학의 학문적 정체성 정립이 다. 이를 위해서는 한국 스포츠윤리학이 연구해야 될 지향점을 찾고, 스포츠윤리학의 연구영역과 연구방법론, 그리고 그 근간이 되는 이론적 틀을 도출하는 연구가 활성화되어야 할 것이다. 〔결론) 어떤 학문 분야의 성립 과 성공적인 발전은 그것을 전공하는 학자들, 그들의 수많은 연구물과 실제 현장에서의 실천적 성과, 다양하고 현실적인 정책적·제도적 뒷받침, 그리고 그 학문의 연구내용과 방법론에 대한 지속적인 논의와 합의들이 축적 되었을 때 가능한 일이다. 스포츠윤리학도 다양한 학자들이 스포츠에서 발생하는 윤리적 이슈와 쟁점에 대해 연구하고, 연구자간 학술적 교류를 통해 이론적 기반과 연구방법의 타당성을 지속적으로 논의하며, 그것이 실 제 현장에 보급·확산되어 스포츠의 바람직한 발전과 방향을 제시하는 나침반의 역할을 할 수 있을 때, 학(學) 으로서의 체계와 위상을 정립하고 그 전문성도 제고할 수 있을 것이다.

주요어: 스포츠윤리학, 스포츠철학, 역사, 과제, 전망 